\title{
Organizational Factors Affecting Charitable Giving in the Environmental Nonprofit Context
}

\author{
Chiara Leardini ${ }^{1, *(\mathbb{D}}$, Gina Rossi $^{2}(\mathbb{C})$ and Stefano Landi ${ }^{3}(\mathbb{C})$ \\ 1 Department of Business Administration, University of Verona, 37129 Verona, Italy \\ 2 Department of Economics and Statistics, University of Udine, 33100 Udine, Italy; gina.rossi@uniud.it \\ 3 Department of Management, University of Ca' Foscari-Venice, 30121 Venice, Italy; stefano.landi@unive.it \\ * Correspondence: chiara.leardini@univr.it; Tel.: +39-0458-028-222
}

Received: 17 September 2020; Accepted: 27 October 2020; Published: 28 October 2020

\begin{abstract}
Nonprofit organizations operating in the environmental protection and conservation sector face challenging fundraising issues in collecting from individual donors the money needed to accomplish their goals. The purpose of this study was to investigate which organizational factors can play a role in influencing the ability of these organizations to collect charitable contributions. By applying an extended version of the economic model of giving to a sample of 142 environmental nonprofits from the United States, the results of the regression analyses show that the following factors allow these organizations to attract more donations: devoting a high percentage of donations to programs, promoting the organization's image through fundraising activities, having a large amount of assets that ensures a sustainable financial structure, and providing online information that demonstrates how the organization has dealt with its mission. Moreover, the study reveals that providing high amounts of disclosure on the organization's website can have a conditional effect on fundraising expenses by boosting the positive effect of these expenses on donations. The results of this study contribute to the debate on the effectiveness of organizational factors in attracting funds from donors willing to support environmental nonprofits.
\end{abstract}

Keywords: nonprofit organizations; environment; donations; fundraising; online disclosure

\section{Introduction and Literature Review}

Given that concern for the natural environment has grown over time, many nonprofit organizations have placed environmental protection and conservation at the center of their mission in an attempt to introduce the social and ecological dimensions of sustainable development into the social conscience and governments' priorities and policies [1-4]. In recent decades, environmental nonprofits have helped to develop laws and regulations, conducted scientific research, managed environmental disasters, litigated cases, and supported projects locally, nationally, and globally to preserve the world's natural capital. At the national level, environmental nonprofits supply much of the shortfall in environmental conservation spending by local governments, and at the international level, such organizations channel funds from donors to poorer nations where the environment is most imperiled [5-7].

To accomplish their goals, environmental nonprofits face challenging fundraising issues because of the significant costs they incur in improving environmental problems [8]. The funding paths that they usually take to raise the necessary amounts of money are generally based on individual donations $[5,9,10]$ because these organizations serve causes that are deeply important to many people at all income levels and take actions that provide a collective benefit [11]. Thus, it is crucial that the donor community channel sufficient resources into environmental causes.

To compete in the charitable contributions market, environmental nonprofits need to signal to donors that they are worthy of their donations [12]. Credible signals of the virtue of nonprofits can help 
these organizations to attract donors by conveying that the organization is performing as promised to protect and conserve the environment $[13,14]$. Online accountability has been found to have important potential to increase the observability of the signal at a limited cost despite environmental nonprofits having experienced difficulties in attracting visitors to their websites [15].

Previous studies have demonstrated that donors reward nonprofits that disclose large quantities of financial and performance information online [16-18]. Given that the nature of nonprofit activities lacks a purely lucrative purpose, earnings surplus is not a meaningful indicator of the success of a nonprofit organization. Therefore, financial information that is disclosed must be accompanied by information on the organization's main objectives, strategies, and programs [19]. Using an extended version of the economic model of giving originally proposed by Weisbrod and Dominguez [20], prior research has reported that the amount of donations an organization receives is related to the amount of financial and performance information it discloses on its website. For example, focusing on 80 Spanish nongovernment development organizations, Gandía [16] found that a higher quantity of information disclosed online by nonprofits about the use of funds, programs realized, and financial results increased the amount of donations. In addition, Saxton et al. [18] highlighted that the presence of annual reports on nonprofits' websites had a positive effect on donations in United States (US) nonprofit organizations operating in the sectors of the arts, education, environment and animals, health, human services, international aid, and public benefit. Furthermore, in a study on a sample of industry-diverse nonprofit organizations, Harris and Neely [17] found that providing information that exceeds mandatory disclosure requirements led to a higher amount of donations than did providing less and basic online information.

According to the economic model of giving, the amount of donations an organization receives is also a function of a set of other organizational factors. Donors care about the price of donation, that is the cost of purchasing one dollar of output $[20,21]$. Thus, a higher price is usually negatively associated with the amount of donations [22]. In addition, given that the age of an organization is associated with a good reputation [20], the older age of nonprofits typically has a positive effect on the amount of charitable contributions $[23,24]$. A positive influence on donations is also associated with the amount of fundraising expenses because these expenses have an advertising effect [18,25-27]. Finally, administrative expenses usually have a negative impact on charitable contributions because they are considered a diversion of resources from projects that have an impact for the community and fulfil the promised aim of the nonprofit organization [20,22,24,28-30].

Prior studies have warned that online disclosure and these other organizational factors can produce significantly different effects on donations depending on the sector in which a nonprofit operates $[10,22,31]$. Despite the increasing importance of nonprofits operating in the environment conservation and protection sector, little is still known about which factors most affect the ability of such organizations to attract charitable giving.

Focusing on the experience of a sample of US nonprofits rated by Charity Navigator and operating in the environmental protection and conservation sector, the purpose of this study is to investigate which organizational factors play a role in influencing nonprofits' ability to collect donations. According to the extended version of the economic model of giving [18], the factors considered in the analysis are the price of donation, organization age and size, overhead costs (fundraising and administrative expenses), and online disclosure.

The main findings reveal that online disclosure does not have a direct significant influence on the amount of donations collected by the US environmental nonprofits under study. Rather, high levels of disclosure act as a booster of the effect of fundraising activities on the amount of donations. The factors that mainly affect the ability of an organization to collect charitable contributions are the price of donation, the costs spent for raising funds and the size of the organization. In contrast, the administrative expenses and organization age were found to play no role in attracting donations for environmental nonprofits. 


\section{Materials and Methods}

\subsection{Sample and Data Collection}

For more than 50 years, attention to environmental protection and natural resource management issues has been central to US society [2]. Thus, US nonprofits play a key role in addressing the most difficult challenges in preserving the environment. Given that environmental nonprofits are currently predominantly funded through philanthropy [10], these organizations face the challenge of competing for charitable contributions. Creating a web presence and sharing information on the organization website can make the difference when it comes to donors.

This study examined US environmental nonprofits rated by Charity Navigator, which is one of the most utilized watchdog agencies that monitor nonprofit expenditure and help donors make decisions when making a charitable contribution [32]. More specifically, Charity Navigator makes free to donors a rating system that examines a charity's financial health, accountability and transparency. The sample for this study was built by selecting nonprofits belonging to the category "Environment" and listed under the cause "Environment protection and conservation". As an additional search field, we focused on the scope of work and considered nonprofits operating both nationally and internationally. After removing organizations with inaccessible online information, the final sample was composed of 142 organizations.

A database was created for collecting the financial, organizational, and disclosure data for the year 2018. Financial data that were useful for the analysis (i.e., donations, program, administrative and fundraising expenses, revenues, and size) were acquired directly from Charity Navigator or, if not available there, were retrieved from the Internal Revenue Service (IRS) Form 990 published on the website of the organization. Organization age and overall disclosure data were obtained from the websites of the organizations in the sample. The content monitored to collect data on online disclosure followed the framework proposed by Saxton and Guo [23] to consider the disclosure of financial information (i.e., annual report, IRS Form 990, audited financial report, administrative costs, and investment policy) and of the performance information (i.e., organizational mission, vision, and values; history; priorities and strategic objectives; and projects supported). Table 1 presents the items included in the database.

Table 1. Financial, organizational and disclosure data.

\begin{tabular}{ccc}
\hline Category & Item & Source \\
\hline Financial data & Donations & IRS Form 990 \\
& Program expenses & IRS Form 990 \\
& Administrative expenses & IRS Form 990 \\
& Fundraising expenses & IRS Form 990 \\
& Revenues & IRS Form 990 \\
Organizational data & Size & IRS Form 990 \\
Disclosure data & Age & Website \\
& Annual report & Website \\
& IRS Form 990 & Website \\
& Audited financial report & Website \\
& Administrative costs & Website \\
& Investment policy & Website \\
& Mission, vision, and values & Website \\
& History & Website \\
& Priorities and strategic objectives & Website \\
& Projects supported & Website \\
\hline
\end{tabular}

The presence or absence on the organizations' websites of the items used to measure disclosure was mapped. That is, as suggested by prior studies $[16,18,23,33]$, an organization was assigned a score of one if its websites which disclosed the information item, and zero otherwise. 


\subsection{Method}

Within the nonprofit arena, the economic model of giving [20] served as a baseline model for several empirical studies [22]. According to this model, donations are a function of price, administrative expenses, fundraising and organization age, and serve as the proxy for demand for a nonprofit organization's output. To investigate the factors that most contribute to the amount of donations received by environmental nonprofits, this study used an extended version of the economic model of giving by incorporating the effect of the presence of online information on the amount of donations received [18], as in the following model:

$$
\begin{aligned}
\text { lnDonations }_{i t}=\beta_{0}+\beta_{1} \text { InPrice }_{i t} & +\beta_{2} \text { lnAdministrative expenses }_{i t}+\beta_{3} \text { lnFundraising }_{i t}+\beta_{4} \text { InAge }_{i t} \\
& +\gamma X_{i t}+\delta \text { Disclosure }_{i t}+\varepsilon_{i t}
\end{aligned}
$$

InDonations $_{i t}$ is the natural log of the amount of charitable contributions received by an environmental nonprofit. InPrice $i t$ is the price of donation (i.e., the cost to a donor of purchasing one dollar of output). According to previous studies [21,22,34], this price is measured as the inverse of the ratio of program expenses to total expenses. InAdministrative expenses ${ }_{i t}$ is measured as the ratio of the amount of administrative costs to total expenses [35]. $\ln$ Fundraising $g_{i t}$ is the natural log of fundraising expenses. $\ln A g e_{i t}$ is the age of the organization in years. $X_{i t}$ includes size and donor dependence as control variables [18]. InSize is the natural log of the amount of assets at the end of the year, while Donor dependence is the incidence of donations to the total revenues of the organization. Disclosure ${ }_{i t}$ is an index that measures the presence on nonprofits' websites of the disclosure items listed in Table 1. More specifically, this index consists of three measures: Financial Disclosure ${ }_{i t}$, Performance Disclosure ${ }_{i t}$, and Total Disclosure ${ }_{i t}$. Financial Disclosure $i t$ is the total number of financial disclosure items on each organization's website. Given there are five items for financial disclosure and that an item is scored one if present on the website and zero if not, this index scores between zero and five. Performance Disclosure $_{i t}$ is the total number of performance disclosure items on each organization's website and scores between zero and four because there are four items of performance disclosure. Total Disclosure $i t$ is the sum of Financial Disclosure $i t$ and Performance Disclosure $i t$, and scores between zero and nine.

\section{Results}

\subsection{Descriptive Analysis}

Table 2 contains some descriptive statistics for the 142 US environmental nonprofits under examination. The sample contains young and old organizations, with an age range from 10 to 143 years. As the data demonstrate, there is a high variability in some variables, particularly for Donations, Fundraising, and Size. In addition, the variable of Size has two organizations with negative values for their net assets. The average level of Donor dependence is high (0.75), that is, the sustainability of US environmental nonprofits largely depends on their ability to attract contributions from individual donors.

The analysis revealed that the US environmental nonprofit organizations under study disclose on average five of nine items. None of the organizations offered complete online disclosure, that is, no organization provided information on all the items investigated in this analysis. It is interesting to note a preference to disclose performance information (three items on average versus less than two items for financial disclosure). All but one organization presented their organizational history on their website. The items most commonly disclosed online were the projects supported (86\%); mission and values (66\%); IRS Form 990 (66\%); audited financial report (62\%); and priorities and strategic objectives (61\%). Conversely, only $14 \%$ of the organizations offered specific information on administrative costs and only $1.5 \%$ reported their investment policies. 
Table 2. Descriptive statistics ${ }^{1}$.

\begin{tabular}{cccc}
\hline Variable & Mean (SD) & Min & Max \\
\hline Donations & $19,536,642$ & 163,731 & $829,799,213$ \\
& $(31,225,638)$ & & \\
Price of donation & 0.75 & 0.20 & 2.20 \\
& $(0.25)$ & & 0.39 \\
Administrative expenses & 0.11 & 0.01 & \\
& $(0.07)$ & & \\
Fundraising & $2,139,301$ & 2878 & $122,795,011$ \\
Age & $(10,745,134)$ & & 143 \\
Size & 33.6 & 10 & \\
& $(22.0)$ & & $6,598,473,145$ \\
Donor dependence & $702,26,673$ & $-151,444$ & 1 \\
& $(55,6310,233)$ & & \\
& 0.75 & 0 & \\
\hline
\end{tabular}

${ }^{1}$ Values expressed in USD.

Table 3 presents the summary of the analysis of online disclosure.

Table 3. Disclosure items statistics.

\begin{tabular}{|c|c|c|c|c|}
\hline Category & Item & $\begin{array}{l}\text { No. of Nonprofits } \\
\text { Disclosing the } \\
\text { Item }(\%)\end{array}$ & $\begin{array}{l}\text { Average No. } \\
\text { of Items per } \\
\text { Organization } \\
\text { (SD) }\end{array}$ & Min-Max \\
\hline \multirow[t]{6}{*}{ Financial disclosure } & & & $1.9(1.3)$ & $(0-4)$ \\
\hline & Annual report & $79(55.6 \%)$ & & \\
\hline & IRS Form 990 & $94(66.2 \%)$ & & \\
\hline & Audited financial report & $89(62.7 \%)$ & & \\
\hline & Administrative costs & $21(14.8 \%)$ & & \\
\hline & Investment policy & $2(1.5 \%)$ & & \\
\hline \multirow[t]{5}{*}{ Performance disclosure } & & & $3.0(0.9)$ & $(0-4)$ \\
\hline & $\begin{array}{c}\text { Mission, vision and } \\
\text { values }\end{array}$ & $94(66.2 \%)$ & & \\
\hline & History & $141(99.1 \%)$ & & \\
\hline & $\begin{array}{c}\text { Priorities and strategic } \\
\text { objectives }\end{array}$ & $84(61.3 \%)$ & & \\
\hline & Projects supported & $123(86.6 \%)$ & & \\
\hline Total disclosure & & & $5.0(2.0)$ & $(0-8)$ \\
\hline
\end{tabular}

\subsection{Statistical Analysis}

This study tested three regression models on the log of donations by using ordinary least squares (OLS) regressions (see Table 4). OLS regressions estimate parameters in the regression models by minimizing the sum of the squares of the differences between the values of the dependent variable observed in the dataset and the values predicted by a linear function. In this study, we used OLS regressions to estimate the net effect of some independent variables on donations. That is, we analyze the relative change in the amount of charitable contributions due to a relative change in one of the organizational factors included in the extended version of the economic model of giving, all other factors being equal.

Diagnostic tests were performed to verify whether the data respected key classical linear regression assumptions. The tests indicated homoscedasticity, no multicollinearity (VIFs $<3.3$ for Models 1 and 2 , VIFs $<3.5$ for Model 3), and no autocorrelation among the residuals (Durbin-Watson test $=1.89$ to 1.91$)$. 
Table 4. Ordinary least squares (OLS) regressions on the log of donations.

\begin{tabular}{|c|c|c|c|}
\hline & Model 1 & Model 2 & Model 3 \\
\hline Constant & $\begin{array}{l}1.680 \\
(9.16)\end{array}$ & $\begin{array}{l}1.591 \\
(8.86)\end{array}$ & $\begin{array}{l}1.811 \\
(9.56)\end{array}$ \\
\hline Price & $\begin{array}{c}-2.759 * * * \\
(-4.48)\end{array}$ & $\begin{array}{c}-2.885^{* * * *} \\
(-5.01)\end{array}$ & $\begin{array}{l}-2.775 \\
(-4.93)\end{array}$ \\
\hline Administrative expenses & $\begin{array}{c}0.171 \\
(1.788)\end{array}$ & $\begin{array}{l}0.187 \\
(1.97)\end{array}$ & $\begin{array}{l}0.153 \\
(1.59)\end{array}$ \\
\hline Fundraising & $\begin{array}{c}0.542^{* * *} \\
(11.67)\end{array}$ & $\begin{array}{c}0.543^{* * *} \\
(11.89)\end{array}$ & $\begin{array}{c}0.529 * * * \\
(11.46)\end{array}$ \\
\hline Age & $\begin{array}{l}-0.179 \\
(-1.80)\end{array}$ & $\begin{array}{l}-0.190 \\
(-1.91)\end{array}$ & $\begin{array}{l}-0.156 \\
(-1.57)\end{array}$ \\
\hline Size & $\begin{array}{c}0.308^{* * *} \\
(7.245)\end{array}$ & $\begin{array}{c}0.320 * * * \\
(7.69)\end{array}$ & $\begin{array}{c}0.308^{* * *} \\
(7.33)\end{array}$ \\
\hline Donor dependence & $\begin{array}{c}0.599 * * * \\
(7.34)\end{array}$ & $\begin{array}{c}0.614^{* * *} \\
(7.56)\end{array}$ & $\begin{array}{c}0.586^{* * *} \\
(7.13)\end{array}$ \\
\hline Total disclosure & $\begin{array}{c}0.019 \\
(1.499)\end{array}$ & & $\begin{array}{l}0.002 \\
(0.13)\end{array}$ \\
\hline Financial disclosure & & $\begin{array}{c}-0.06 \\
(-0.38)\end{array}$ & \\
\hline Performance disclosure & & $\begin{array}{l}0.062 \text { * } \\
(2.485)\end{array}$ & \\
\hline High total disclosure * fundraising & & & $\begin{array}{l}0.019 * \\
(2.295)\end{array}$ \\
\hline Adj. $R^{2}$ & 0.881 & 0.881 & 0.884 \\
\hline $\mathrm{F}$ & $131^{* * *}$ & $118^{* * *}$ & $118^{* * *}$ \\
\hline
\end{tabular}

All models in Table 4 are significant and present an adjusted $\mathrm{R}^{2}$ ranging from 0.881 to 0.884 . According to previous studies, Fundraising, Size, and Donor Dependence were significant and positively related to Donations, thereby indicating that large environmental nonprofits with higher donor dependence and fundraising costs are able to attract more donations. Conversely, Price has a negative effect on charitable contributions, that is, the more the cost of giving, the less the amount of donations collected. Age and Administrative expenses are not statistically significant.

Model 1 incorporates the Total Disclosure to test whether the presence of an online disclosure is positively associated with the amount of Donations. The results indicate that online disclosure did not have a significant effect on the amount of donations. In Model 2, Total Disclosure was replaced with the two disaggregated partial indicators Financial Disclosure and Performance Disclosure to test whether they affected the capacity of environmental nonprofits to attract donations. The analysis demonstrated that only the presence of performance disclosure items was associated with greater levels of charitable contributions. In contrast, the disclosure of financial items was not associated with greater levels of charitable contributions.

Given that Total Disclosure in Model 1 was not statistically significant, we proposed a third model for better understanding the role played by the disclosure variable. Specifically, Model 3 introduces a dichotomous variable named High Total Disclosure that was equal to one for environmental nonprofits that presented online information for at least seven disclosure items, and zero otherwise. The dummy variable was used in the regression analysis to assess the effect of the organizational factors when moderated by a high level of disclosure. The interaction terms were introduced one at a time in Equation (1) for each organizational factor. Model 3 shows that there is a significant association between the interaction variable High Total Disclosure * InFundraising and the amount of Donations. In other words, high numbers of items disclosed on the environmental nonprofits' website influenced the sensitivity of the amount of donations to fundraising expenses. This means that, with investments in fundraising being equal, organizations with higher levels of total disclosure receive a greater amount of donations. 


\section{Discussion}

The experience of the US environmental nonprofits examined in this study suggests that several factors play a role in influencing the ability of these organizations to attract charitable contributions.

Consistent with prior literature on nonprofit organizations [18,27], allocating resources to fundraising activities is crucial for attracting donations in the environmental nonprofit sector. Activities such as postal and email campaigns, television and internet advertisement, and fundraising events contribute to advertising the actions of an organization and increasing its visibility, which is a necessary condition for soliciting money to finance the cause to which a nonprofit is dedicated [25-27]. Additionally, in line with previous studies, the amount of donations collected by environmental nonprofits is affected by the price of donation [20-22]. Specifically, donors dislike donating to organizations that have a high price of donation because a higher price means that a large portion of the donation is spent on administrative and fundraising expenses. That is, donors are sensitive to the amount of resources devoted to the projects run by nonprofits and tend to reward by giving greater donations to organizations that allocate a higher percentage of their resources to project expenses.

However, the study findings related to the role of administrative expenses diverge from previous findings. While previous research has usually found a negative relationship between donations and administrative costs because these costs are considered to divert resources from projects that create impact $[20,22,24,28-30]$, the present study found that the capacity of environmental nonprofits to collect charitable contributions is not affected by their level of administrative spending. This means that donors who contribute to financing the protection and conservation of the environment seem not to be sensitive to the amount of resources allocated to administration, management, and general expenses. This follows that administrative costs are not interpreted by donors as a signal of inefficiency in the use of the money raised through donations [22]. Thus, in relation to the allocation of financial resources, the findings of this study suggest that the most critical decisions on how to use the received donations relate to the projects run by environmental nonprofits and the fundraising activities of these nonprofits.

Contrary to the expectations of the economic model of giving $[23,24,30]$, the age of nonprofit organizations operating in the environmental protection and conservation sector does not affect the amount of donations received. Despite attention to environmental issues being central to US society for many years [2], organization age was not found to contribute to signaling reputation, with both young and old nonprofits receiving an equal amount of donations. An organization's size seems to have a more influential role in attracting donations. With all other factors being equal, larger environmental nonprofits collect greater amounts of charitable contributions, thus confirming a behavior that is common in the broader nonprofit sector $[17,22]$. A possible explanation of the effect of size on donations is that organizations with higher assets are considered more stable and capable of surviving in the long term in an increasingly turbulent context in which building a sustainable organizational structure has become critical for nonprofits in continuing their ability to fulfil their mission.

The effect of the disclosure variable on the amount of donations collected by US environmental nonprofits is of great interest. Three principal considerations can be developed.

First, surprisingly, the results indicate that there is no significant relationship between the amount of donations an environmental nonprofit receives and the total extent of online disclosure. That is, the number of items disclosed on the website does not affect the ability of an organization to attract charitable contributions. This means that disseminating large amounts of online information is not valuable in maintaining competitiveness in the charitable contributions market. While prior studies on nonprofit organizations have found that the quantity of information disclosed is important [14,16-18], in this study on the environmental protection and conservation sector, disclosing information on several organizational aspects (e.g., financial results; administrative costs; investment policy; organizational mission, vision, and values; history; priorities and strategic objectives; and projects supported) seems not help nonprofits attract donations.

Second, while the quantity of online disclosure does not seem to affect the amount of donations, the type of disclosure does. This study found that to compete successfully in gaining charitable 
contributions, environmental nonprofits should signal to donors that they are performing as promised for the protection and conservation of the environment [14]. When total disclosure is disaggregated into discrete measures of financial and performance disclosure, the results demonstrate that performance disclosure has a consistently positive association with the amount of donations. That is, providing information on goals, outcomes, and projects realized results in increased donations [18]. In contrast, information on the financial sustainability of an environmental nonprofit seems not to be critical given that the effect of the financial disclosure items on donations disappears when total disclosure is disaggregated into its various components. Thus, in the environmental nonprofit sector, performance disclosure is more relevant than financial disclosure. A possible explanation for the importance of performance disclosure is that this type of information is difficult to find outside an organization's website. Therefore, donors tend to reward with higher donations nonprofits that provide evidence on their own websites of nonfinancial information about the goals they are attempting to achieve and the outputs, outcomes, and impacts they have achieved. Conversely, disclosing large amounts of financial information fails to be associated with greater donations because this information is often widely available for donors on third-party websites such as Charity Navigator [18]. Therefore, environmental nonprofits are encouraged to increase the online availability of their performance information.

Third, although overall online disclosure was not found to be directly associated with donors' contributions, providing information for many financial and performance items boosts the positive effect of fundraising on donations. That is, the positive effect of fundraising expenses on donations increases when these expenses are combined with a high level of overall disclosure. Therefore, when the fundraising costs for different environmental nonprofits are equal, these organizations receive more donations by increasing the quantity of disclosure on their website. This evidence suggests that online disclosure plays an additional informational role beyond that of fundraising by offering a continuously available and wider type of information that adds to the limited information disseminated through fundraising campaigns and materials [18].

\section{Conclusions}

The growing need to protect and preserve the natural environment has led environmental nonprofit organizations to consider how they can increase donations to achieve their mission. This study contributes to understanding the variables that affect US environmental nonprofits' capacity to compete in the charitable contributions market.

The extended version of the economic model of giving tested in this study revealed that donors are affected by the price of donation, fundraising costs, and organizational size. Thus, devoting a high percentage of donations to projects, promoting the organization's image through fundraising activities, and having a large amount of assets that ensures a sustainable financial structure are important in attracting donations for the nonprofit organizations in the environmental protection and conservation sector.

Among the important decisions made by managers of nonprofit organizations is how much information they should disclose about their financial and social performance, thus this study makes a practical contribution by demonstrating that it is more important to provide online goal-oriented and performance information that demonstrates how a nonprofit has managed to achieve its mission to safeguard the natural environment. In addition, providing high levels of overall disclosure can have a conditional effect on fundraising expenses by boosting the positive effect of these expenses on donations.

From a theoretical perspective, the results of this study identify the specific effects of online disclosure by environmental nonprofits compared with other types of nonprofits, and add to the understanding of the signaling relevance of online information for promoting donations in the environmental protection and conservation sector. Specifically, the results reveal that high amounts of online information have a boosting effect on fundraising in collecting donations. From a practical perspective, this study helps environmental nonprofits competing for charitable contributions to identify 
the disclosure items that are more successful in influencing donors' sensitivity and willingness to donate. The results also contribute to the debate on the effectiveness of the other variables (i.e., price of donation, organization age and size, fundraising, and administrative expenses) considered by the economic model of giving in attracting donations from individuals willing to support environmental nonprofits.

This study is not without limitations, as the topic is very nuanced. In scrutinizing the variables that affect environmental nonprofits' capacity to compete in the market of charitable contributions, further research could investigate the role of governance structures for better understanding if the board composition and size could be related to donations. Moreover, it would be interesting to survey differences in donor patterns considering, for example, small and large donors, or regular and one-time donors. These secondary data contribute to a better knowledge of how organizational factors affect contributions depending on the characteristics of the donors. Finally, as US environmental nonprofits under scrutiny largely depend on donations for their survival, further research could investigate more in depth how public policies can affect the amount of charitable contributions to these organizations. Tax deduction for charitable contributions aside [20], prior studies considering the broader nonprofit arena found that government grants can produce both a crowding-in and a crowding-out effect. In the first case, government support for nonprofits may encourage private giving as donors perceive it as a stamp of approval signaling an organization's merit and virtue [36]. In the second case, donors may perceive public dollars as substitutes for their donations and thus give less, forcing nonprofits to adjust their fundraising efforts $[37,38]$. In both cases, more investigation is required. In this vein, additional research should be devoted also to the incentives for impact investing tools, such as social impact bonds, as they could produce the same crowding-out effect of more traditional government funding [39].

Despite that much can still be investigated, this study shows that what makes environmental nonprofits special is that their continuity and sustainability depend on the combined investment in online disclosure and fundraising, and cannot disregard sharing information on the goals, strategies and activities they perform.

Author Contributions: Although the work is a result of joint efforts by all authors, the paper design and conceptualization are ascribable to C.L. and G.R. The methodology and formal analysis are ascribable to S.L. All authors were involved in writing the original draft, reviewing, and editing. All authors have read and agreed to the published version of the manuscript.

Funding: This research received no external funding.

Conflicts of Interest: The authors declare no conflict of interest.

\section{References}

1. Handy, F. Advocacy by environmental nonprofit organisations. An optimal strategy for addressing environmental problems? Int. J. Soc. Econ. 2001, 28, 648-666. [CrossRef]

2. Konisky, D.M. Introduction: US environmental policy research in uncertain times. In Handbook of US Environmental Policy; Konisky, D.M., Ed.; Edward Elgar Publishing: Cheltenham, UK, 2020; pp. 1-9.

3. Valentinov, V.; Vaceková, G. Sustainability of rural nonprofit organizations: Czech Republic and beyond. Sustainability 2015, 7, 9890-9906. [CrossRef]

4. Daub, C.H.; Scherrer, Y.M.; Verkuil, A.H. Exploring reasons for the resistance to sustainable management within non-profit organizations. Sustainability 2014, 6, 3252-3270. [CrossRef]

5. Armsworth, P.R.; Fishburn, I.S.; Davies, Z.G.; Gilbert, J.; Leaver, N.; Gaston, K.J. The size, concentration, and growth of biodiversity-conservation nonprofits. BioScience 2012, 62, 271-281.

6. Brooks, T.M.; Mittermeier, R.A.; da Fonseca, G.A.B.; Gerlach, J.; Hoffmann, M.; Lamoreux, J.F.; Mittermeier, C.G.; Pilgrim, J.D.; Rodrigues, A.S.L. Global biodiversity conservation priorities. Science 2006, 313, 58-61. [CrossRef] [PubMed]

7. Shaffer, M.L.; Scott, J.M.; Casey, F. Noah's options: Initial cost estimates of a national system of habitat conservation areas in the United States. BioScience 2002, 52, 439-443. [CrossRef] 
8. Stevens, D.P.; Hollier, B.N.G.; Slatten, L.A.D. Web-based accountability for nonprofits: Environmental quality protection and beautification category. J. Leadersh. Account. Ethics 2018, 15, 41-54.

9. Greenspan, I.; Handy, F.; Katz-Gerro, T. Environmental philanthropy: Is it similar to other types of environmental behavior? Organ. Environ. 2012, 25, 111-130. [CrossRef]

10. Morris, G.; Roberts, D.; MacIntosh, J.; Bordone, A. The Financial Health of the United States Nonprofit Sector; Oliver Wyman: New York, NY, USA, 2018.

11. Foster, W.L.; Kim, P.; Christiansen, B. Ten nonprofit funding models. Stanford. Soc. Innov. Rev. 2009, 7, 32-39.

12. Greenberg, J.; MacAulay, M. NPO 2.0? Exploring the web presence of environmental nonprofit organizations in Canada. Glob. Media J. Can. Ed. 2009, 2, 63-88.

13. Connolly, B.L.; Certo, S.T.; Ireland, R.D.; Reutzel, C.R. Signaling theory: A review and assessment. J. Manag. 2011, 37, 39-67. [CrossRef]

14. Ortega-Rodríguez, C.; Licerán-Gutiérrez, A.; Moreno-Albarracín, A.L. Transparency as a key element in accountability in non-profit organizations: A systematic literature review. Sustainability 2020, 12, 5834. [CrossRef]

15. Pollach, I.; Treiblmaier, H.; Floh, A. Online fundraising for environmental nonprofit organizations. In Proceedings of the 38th Annual Hawaii International Conference on System Sciences, Big Island, HI, USA, 3-6 January 2005.

16. Gandía, J.L. Internet disclosure by nonprofit organizations: Empirical evidence of nongovernmental organizations for development in Spain. Nonprofit Volunt. Sect. Q. 2011, 40, 57-78. [CrossRef]

17. Harris, E.E.; Neely, D. Determinants and consequences of nonprofit transparency. J. Account. Audit. Financ. 2018. [CrossRef]

18. Saxton, G.; Neely, D.G.; Guo, C. Web disclosure and the market for charitable contributions. J. Account. Public Policy 2014, 33, 127-144. [CrossRef]

19. Fritz, T.M.; von Schnurbein, G. Beyond socially responsible investing: Effects of mission-driven portfolio selection. Sustainability 2019, 11, 6812. [CrossRef]

20. Weisbrod, B.A.; Dominguez, N.D. Demand for collective goods in private markets: Can fundraising expenditures help overcome free-rider behavior? J. Public Econ. 1986, 30, 83-95. [CrossRef]

21. Wong, J.; Ortmann, A. Do donors care about the price of giving? A review of the evidence, with some theory to organise it. Voluntas 2016, 27, 958-978. [CrossRef]

22. Jacobs, F.A.; Marudas, N.P. The combined effect of donation price and administrative inefficiency on donations to US nonprofit organizations. Financ. Account. Manag. 2009, 25, 33-53. [CrossRef]

23. Saxton, G.D.; Guo, C. Accountability online: Understanding the web-based accountability practices of nonprofit organizations. Nonprofit Volunt. Sect. Q. 2011, 40, 270-295. [CrossRef]

24. Tinkelman, D.; Mankaney, K. When is administrative efficiency associated with charitable donations? Nonprofit Volunt. Sect. Q. 2007, 36, 41-64. [CrossRef]

25. Burkart, C.; Wakolbinger, T.; Toyasaki, F. Funds allocation in NPOs: The role of administrative cost ratios. Cent. Eur. J. Oper. Res. 2018, 26, 307-330. [CrossRef] [PubMed]

26. Frumkin, P.; Kim, M.T. Strategic positioning and the financing of nonprofit organizations: Is efficiency rewarded in the contributions marketplace? Public Admin. Rev. 2001, 61, 266-275. [CrossRef]

27. Sarikaya, S.; Buhl, H.U. The challenge of resource allocation in the nonprofit sector: Determining the right amount of fundraising expenses. J. Nonprofit Public Sect. Mark. 2020. [CrossRef]

28. Ashley, S.; Faulk, L. Nonprofit competition in the grants marketplace: Exploring the relationship between nonprofit financial ratios and grant amount. Nonprofit Manag. Leadersh. 2010, 21, 43-57. [CrossRef]

29. Gneezy, U.; Keenan, E.A.; Gneezy, A. Avoiding overhead aversion in charity. Science 2014, 346, 632-635. [CrossRef]

30. Tinkelman, D. Factors affecting the relation between donations to not-for-profit organizations and an efficiency ratio. R. Gov. Nonprofit Account. 1999, 10, 135-361.

31. Bekkers, R.; Wiepking, P. A literature review of empirical studies of philanthropy: Eight mechanisms that drive charitable giving. Nonprofit Volunt. Sect. Q. 2011, 40, 924-973. [CrossRef]

32. Blouin, M.C.; Lee, R.L.; Erickson, G.S. The impact of online financial disclosure and donations in nonprofits. J. Nonprofit Public Sect. Mark. 2018, 30, 251-266. [CrossRef]

33. Rossi, G.; Leardini, C.; Landi, S. The more you know, the more you give: Influence of online disclosure on European community foundations' donations. Nonprofit Manag. Leadersh. 2020, 31, 81-101. [CrossRef] 
34. Trussel, J.M.; Parsons, L.M. Financial reporting factors affecting donations to charitable organizations. Adv. Account. 2008, 23, 263-285. [CrossRef]

35. Ashley, S.R.; Van Slyke, D.M. The influence of administrative cost ratios on state government grant allocations to nonprofits. Public Admin. Rev. 2012, 72, S47-S56. [CrossRef]

36. Smith, T. The impact of government funding on private contributions to nonprofit performing arts organizations. Ann. Public Coop. Econ. 2007, 78, 137-160. [CrossRef]

37. Andreoni, J.; Payne, A. Is crowding out due entirely to fundraising? Evidence from a panel of charities. J. Public Econ. 2011, 95, 334-343. [CrossRef]

38. Kim, M.; Van Ryzin, G.G. Impact of government funding on donations to arts organizations: A survey experiment. Nonprofit Volunt. Sect. Q. 2014, 43, 910-925. [CrossRef]

39. Faulk, L.; Pandey, S.; Pandey, S.K.; Scott Kennedy, K. Donors' responses to profit incentives in the social sector: The entrepreneurial orientation reward and the profit penalty. J. Policy Anal. Manag. 2020, 39, $218-242$. [CrossRef]

Publisher's Note: MDPI stays neutral with regard to jurisdictional claims in published maps and institutional affiliations.

(C) 2020 by the authors. Licensee MDPI, Basel, Switzerland. This article is an open access article distributed under the terms and conditions of the Creative Commons Attribution (CC BY) license (http://creativecommons.org/licenses/by/4.0/). 